\title{
Scale Model of a Soil Aggregate and Associated Organisms: A Teaching Tool for Soil Ecology
}

\author{
Mary Ann Bruns* and Loren B. Byrne
}

\begin{abstract}
Soil is a complex habitat for diverse biota. A significant challenge in teaching soil ecology is our inability to observe organisms as they live and interact in the soil. The objective of this article is to describe an interactive class project to help students visualize the sizes of different groups of soil organisms and to relate these to soil structural components. This project was carried out by students in an upper-level undergraduate soil ecology class. It involved the design and construction of a $4000 \times$ scale model of a soil aggregate and its associated organisms. The body of the model was made from inexpensive, lightweight materials and had a diameter of approximately $1 \mathrm{~m}$ to depict a $0.25-\mathrm{mm}$ aggregate. Students identified and discussed appropriate size ranges and construction materials for the model's bacteria, fungi, nematodes, mites, springtails, and other components. Instructorguided questions addressed size and arrangement of sand, silt, and clay particles; pores; and organic matter in a typical soil aggregate. The model is a useful tool for conveying physical and ecological relationships among soil organisms and is adaptable for use at diverse educational levels.
\end{abstract}

$\mathrm{I}_{\mathrm{s}}^{\mathrm{N}}$ HIS RECENT BOOK, The Future of Life, naturalist E.O. Wilson advocates biodiversity conservation at the microscale. He indicates that most conservation efforts have focused on preserving plants and animals familiar to us because we can actually see them (Wilson, 2002). However, practically nothing is known about losses in diversity of organisms that we do not see, namely microarthropods, protists, and other microorganisms, many of which reside in the soil. Soil microbial communities recycle, retain, and release nutrients to provide ecological support for all life on this planet (Needham et al., 2000). Creative ways are needed to help people visualize micro-communities and to convey their significance in maintaining and sustaining the biosphere.

In this article we describe an interactive class project for building a scale model of a soil aggregate (or ped) and its associated organisms. Design and construction of the model provided integrative, hands-on activities for students in an upperlevel undergraduate soil ecology course and enabled them to visualize soil organisms in relation to the habitat provided by a soil aggregate. This article provides information on teaching objectives, model design, construction materials, and soil biology references that will be useful to others who wish to build similar models.

Department of Crop and Soil Sciences and Intercollege Graduate Degree Program in Ecology, 116 ASI Bldg, Pennsylvania State Univ., University Park, PA 16802. Received 20 Dec. 2002. *Corresponding author (mvb10@ psu.edu).

Published in J. Nat. Resour. Life Sci. Educ. 33:85-91 (2004). http://www.JNRLSE.org

(C) American Society of Agronomy

677 S. Segoe Rd., Madison, WI 53711 USA

\section{OBJECTIVES}

Key objectives for the soil ecology course were for students to learn characteristics, relative sizes, and functions of soil biota; understand relationships between soil organisms and their habitats; and explain ecological relationships among soil organisms. The aggregate model project provided a focal activity for students to assimilate course information and gain a deeper understanding of the soil habitat, which is a continually changing complex of mineral particles, organic matter, and other soil organisms. The model required students to integrate and apply their knowledge of biogeochemical, predator-prey, and other food web interactions within and among trophic groups found in the soil. The soil aggregate was a logical choice for portraying a soil "ecological unit," because it is a discrete, identifiable association of soil mineral and organic matter and is itself a product of biological activity (Hattori, 1994; Oades, 1993).

The practical goal of this class project was to develop a soil aggregate model for "AgroEcology Day," an event organized for middle school students by the Penn State Department of Crop and Soil Sciences at Rock Springs Agronomy Research Farm in September 2000. The model demonstrated life associated with a typical soil aggregate found near the surface of a pasture or no-till agricultural field. Model components represented different soil organisms, as well as structural particles of sand, silt, clay, and organic matter, all built to the same scale of magnification using low-cost and readily available materials. Students had to consider the practical aspects of making the aggregate model accessible, both literally and conceptually, to audiences outside the university. By making it possible for more people to see their final product, students greatly increased its educational impact.

\section{INSTRUCTOR-GUIDED QUESTIONS}

The design of the aggregate model grew out of students' decisions during class discussions of instructor-guided questions. These questions challenged students to apply fundamental soil science concepts (listed in first column of Table 1) during development of the model. The second, third, and fourth columns in Table 1 present specific information that supports each concept; model design features that incorporate the specific information; and students' conclusions during implementation. During model development, instructorguided questions encouraged students to consider these concepts, which are organized into four main categories of model components: inorganic particles; living organic matter; dead organic matter; and pore spaces (Table 1).

\section{Which Type of Aggregate Should the Model Portray?}

The initial step in model design required students to decide whether their model should portray a microaggregate or a macroaggregate. The distinction between microaggregates $(<2$ to $250 \mu \mathrm{m})$ and macroaggregates $(250$ to $>2000 \mu \mathrm{m})$ is 
Table 1. Learning objectives and means of implementation in the soil aggregate model.

\begin{tabular}{|c|c|c|c|}
\hline Learning objective & Basic information & Design features in model & Student comments \\
\hline $\begin{array}{l}\text { 1. Size of soil aggregate } \\
\text { Soil aggregates vary in size and are } \\
\text { classified as macro- and microaggre- } \\
\text { gates. }\end{array}$ & $\begin{array}{l}\text { Macroaggregates range in size from } 250 \text { to }> \\
2000 \mu \mathrm{m} \text { (Tisdall, 1994). Microaggregates } \\
\text { range in size from }<2 \text { to } 250 \mu \mathrm{m} \text {. }\end{array}$ & $\begin{array}{l}\text { Model portrayed a small macroaggregate } \\
(250 \mu \mathrm{m}) \text {, which would have a diameter of } \\
1 \mathrm{~m} \text { when magnified } 4000 \text { times. }\end{array}$ & $\begin{array}{l}\text { Simpler and more convenient for a } \\
\text { macroaggregate model to be constructed } \\
\text { as one large, irregular sphere, rather than } \\
\text { assembling many smaller "microaggre- } \\
\text { gates." Styrofoam packing from com- } \\
\text { puter boxes would also make a good } \\
\text { lightweight core. }\end{array}$ \\
\hline $\begin{array}{l}\text { 2.Composition of soil aggregate } \\
\text { Soil aggregates are discrete assem- } \\
\text { blages of mineral particles, organic } \\
\text { matter, and pore spaces that contain } \\
\text { water and/or air. }\end{array}$ & $\begin{array}{l}\text { Average composition of soil is about } \\
45-50 \% \text { mineral particles, } 1-5 \% \text { organic } \\
\text { matter, and } 50 \% \text { pore space. }\end{array}$ & $\begin{array}{l}\text { Core of macroaggregate model was made of } \\
\text { two plastic milk crates. Chicken wire was } \\
\text { loosely wrapped around core, covered } \\
\text { with papier maché, and spray painted. } \\
\text { Small microaggregates consisting of floc- } \\
\text { culated clay particles were made of rice } \\
\text { grains glued together in a consistent orien- } \\
\text { tation. }\end{array}$ & $\begin{array}{l}\text { Intermixed mineral and organic compo- } \\
\text { nents could be portrayed as one large, ir- } \\
\text { regular sphere with many holes and de- } \\
\text { pressions. Individual microaggregates in } \\
\text { a real soil aggregate would be difficult } \\
\text { to identify, due to coating and cementa- } \\
\text { tion by organic matter and metal oxides. }\end{array}$ \\
\hline $\begin{array}{l}\text { 3. Inorganic (mineral) particles } \\
\text { Mineral particles are classified by size } \\
\text { as sand, silt, and clay. }\end{array}$ & $\begin{array}{l}\text { Fine, medium, and coarse sand particles } \\
\text { range in size from } 50 \text { to } 250,250-500 \text {, and } \\
>500 \mu \mathrm{m} \text {, respectively. Silt particles are } 2 \\
\text { to } 50 \mu \mathrm{m} \text {, and clays are }<2 \mu \mathrm{m} \text {. } \dagger \text { The per- } \\
\text { centages of sand, silt, and clay in a soil de- } \\
\text { termine its texture (i.e., sandy or clayey). }\end{array}$ & $\begin{array}{l}\text { Fine sand grains }(20 \mathrm{~cm}) \text { and silt particles }(2 \\
\mathrm{cm}) \text { were made from rolled-up balls of } \\
\text { newspaper of appropriate size. Clay parti- } \\
\text { cles were made from rice grains }(2 \mathrm{~mm}) \\
\text { dyed with orange food coloring to resem- } \\
\text { ble iron oxide coatings. }\end{array}$ & $\begin{array}{l}\text { Individual particles would not be obvious } \\
\text { in a real soil aggregate due to binding } \\
\text { and cementation by organic matter and } \\
\text { iron oxides. Overall texture of the soil } \\
\text { (loamy, sandy, clayey) would affect } \\
\text { model's final appearance. }\end{array}$ \\
\hline 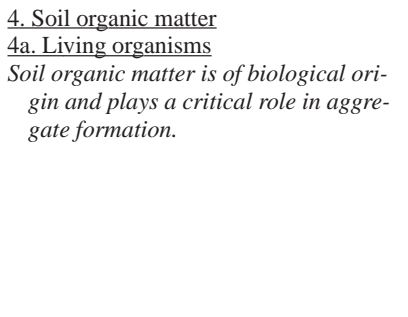 & $\begin{array}{l}\text { Live plant roots, microorganisms, and soil } \\
\text { fauna release sugars and other organic } \\
\text { substances that adsorb to and bind mineral } \\
\text { particles. Fine roots and microbial fila- } \\
\text { ments play an important role in maintain- } \\
\text { ing the integrity of macroaggregates. }\end{array}$ & $\begin{array}{l}\text { Root hair tip made from stuffed nylon stock- } \\
\text { ing and placed on outside of aggregate } \\
\text { model. Unicellular bacteria made from } \\
\text { various seeds. Actinomycetes and fungi } \\
\text { made from strings and thick pipe cleaners, } \\
\text { respectively. Protozoans made from card- } \\
\text { board cutouts. Springtail and mite were } \\
\text { hand-constructed with paperboard and } \\
\text { duct tape. Nematode made from stuffed } \\
\text { tube of fabric. }\end{array}$ & $\begin{array}{l}\text { More bacteria should be placed in area of } \\
\text { root tip to demonstrate that more nutri- } \\
\text { ents are available in the rhizosphere. } \\
\text { Root hair tip and fungal hypha were } \\
\text { placed on the outside of the model to } \\
\text { demonstrate how these would stabilize a } \\
\text { macroaggregate. }\end{array}$ \\
\hline $\begin{array}{l}\text { 4b .Decaying organic matter } \\
\text { Dead plant, animal, microbial, and } \\
\text { waste material exists in various stages } \\
\text { of decomposition, with a range of } \\
\text { sizes. }\end{array}$ & $\begin{array}{l}\text { Particulate organic matter (POM) is insolu- } \\
\text { ble, less decomposed than humus, and } \\
\text { larger than } 50 \mu \mathrm{m} \text {. Humus, the most de- } \\
\text { composed organic material, is dark, amor- } \\
\text { phous }(<2 \mu \mathrm{m}) \text { and resistant to microbial } \\
\text { degradation. }\end{array}$ & $\begin{array}{l}\text { POM was made from irregular chunks of } \\
\text { black-painted sponge. Humus was de- } \\
\text { picted as shapeless bunches of black nylon } \\
\text { net fabric }(1-10 \mathrm{~cm}) \text { and placed in } \\
\text { crevices to demonstrate binding proper- } \\
\text { ties. }\end{array}$ & $\begin{array}{l}\text { POM could provide surfaces for microbes } \\
\text { to attach. More microorganisms should } \\
\text { be placed on and near humus to demon- } \\
\text { strate microbial role in humus forma- } \\
\text { tion. }\end{array}$ \\
\hline $\begin{array}{l}\text { 5. Pore spaces } \\
\text { Soil pores are classified by size as } \\
\quad \text { macropores and micropores. }\end{array}$ & $\begin{array}{l}\text { Macropores are larger than } 80 \mu \mathrm{m} \text {; meso- } \\
\text { pores range in size from } 30 \text { to } 80 \mu \mathrm{m} \text {. Mi- } \\
\text { cropores are }<30 \mu \mathrm{m} \text {. Ultra-micropores are } \\
<5 \mu \mathrm{m} \text { (Tisdall and Oades, 1982). Macro- } \\
\text { pores comprise the spaces between aggre- } \\
\text { gates that permit movement of water, air, } \\
\text { plant roots, and animals through the soil. } \\
\text { Since micropores retain water longer than } \\
\text { macropores, they provide unfavorable } \\
\text { habitat due to oxygen limitation. }\end{array}$ & $\begin{array}{l}\text { Large indentation }(30 \mathrm{~cm}) \text { in the front of the } \\
\text { model depicted a large mesopore contain- } \\
\text { ing bacteria and organic matter. Holes }(2 \\
\mathrm{cm}) \text { were punched through the papier } \\
\text { maché to create ultramicropores and irreg- } \\
\text { ularities. }\end{array}$ & $\begin{array}{l}\text { The outside of the model represented } \\
\text { macropore space where larger biota can } \\
\text { move around. The interior of the model } \\
\text { could contain mesopore-sized spaces } \\
\text { where bacteria can reside. Micropores } \\
\text { are smaller spaces within aggregates that } \\
\text { do not allow larger biota to enter. Bacte- } \\
\text { ria could be excluded from micropores } \\
\text { based on size. Clayey soils would tend } \\
\text { to have more micropores than coarser } \\
\text { soils. }\end{array}$ \\
\hline
\end{tabular}

$\dagger$ USDA classification system.

based on current theories about soil aggregate formation and the development of soil structure proposed by Tisdall and Oades (1982).

Microaggregates are tightly bound by stable organic matter and iron oxides, which are strong enough to remain intact even in soils that are subjected to conventional tillage, that is, moldboard plowing and disking (Six et al., 1998). Macroaggregates, on the other hand, are held together by networks of fine roots and fungal hyphae that are readily disrupted by plowing (Miller and Jastrow, 1990). Soils containing high proportions of stable macroaggregates have undergone less physical disturbance (e.g., pasture, no-till, or reduced tillage soils) than soils dominated by microaggregates (Gale et al., 2000; Six et al., 1998, 1999).

In designing their model, students chose to depict a macroaggregate, which is representative of less-disturbed soils and would be more likely to support higher densities of soil organisms. Some students commented that model design could include internal microaggregate components to reflect aggregate hierarchy theory. Students preferred to portray a macroaggregate from a soil having well-defined crumb structure, since such soils have larger pores, faster water infiltration, and greater aeration for plant roots (Thomas and Phillips, 1979).

\section{How Big Should the Model Be?}

Having decided to represent a macroaggregate, the students next considered the model's scale, or level of magnification. Two practical considerations constrained their choices. Although the class wanted to make the model big enough for the bacteria to be observable, one student pointed out that if they wanted to take the model out of the classroom, it could not be wider than a standard doorway. A scale of 4000x appeared most practical, because it enabled the model $(1.0 \mathrm{~m}$ high by $0.9 \mathrm{~m}$ wide) to pass through doorways and still legitimately portray a macroaggregate, albeit one at the lower limit of the macroaggregate size range (actual diameter of $250 \mu \mathrm{m}$ ) (Tis- 
Table 2. Actual and scaled dimensions of the biological components of the soil aggregate model.

\begin{tabular}{|c|c|c|c|}
\hline Component & Actual width (4000× width) & Actual length ( $4000 \times$ length) & Scale model component dimensions $(4000 \times)$ \\
\hline Unicellular bacteria & $0.3-1 \mu \mathrm{m}(0.12-0.4 \mathrm{~cm})$ & $0.3-2 \mu \mathrm{m}(0.12-0.8 \mathrm{~cm})$ & $\begin{array}{l}0.2 \text { by } 0.5 \mathrm{~cm} \text { (rice grain) } \\
0.3 \text { by } 0.5 \mathrm{~cm} \text { (azuki bean) } \\
0.4 \text { by } 0.5 \mathrm{~cm} \text { (soybean) }\end{array}$ \\
\hline Fungal hyphae & $4-100 \mu \mathrm{m}(1.6-40 \mathrm{~cm})$ & $>10000 \mu \mathrm{m}(>40 \mathrm{~cm})$ & 1 by $1200 \mathrm{~cm}$ (large pipe cleaner) \\
\hline Actinomycete filaments & $0.5-2 \mu \mathrm{m}(0.2-0.8 \mathrm{~cm})$ & 5 to $>1000 \mu \mathrm{m}(2$ to $>40 \mathrm{~cm})$ & 0.2 by $10 \mathrm{~cm}$ (thread) \\
\hline Flagellated protozoans & $5-15 \mu \mathrm{m}(2-6 \mathrm{~cm})$ & $20-50 \mu \mathrm{m}(8-20 \mathrm{~cm})$ & 2 by $6 \mathrm{~cm}$ \\
\hline Ciliated protozoans & $20-50 \mu \mathrm{m}(8-20 \mathrm{~cm})$ & $20-200 \mu \mathrm{m}(8-80 \mathrm{~cm})$ & 8 by $14 \mathrm{~cm}$ \\
\hline Amoebae & $20-50 \mu \mathrm{m}(8-20 \mathrm{~cm})$ & $20-200 \mu \mathrm{m}(8-80 \mathrm{~cm})$ & 8 by $8 \mathrm{~cm}$ \\
\hline Root hairs & $7-20 \mu \mathrm{m}(2.8-8 \mathrm{~cm})$ & $50-300 \mu \mathrm{m}(8-1200 \mathrm{~cm})$ & 0.5 by $8 \mathrm{~cm}$ (yarn) \\
\hline Fine roots & $100-1000 \mu \mathrm{m}(40-4000 \mathrm{~cm})$ & $>10000 \mu \mathrm{m}(>40000 \mathrm{~cm})$ & $25 \mathrm{~cm}$ wide \\
\hline Nematodes & $20-500 \mu \mathrm{m}(8-20 \mathrm{~cm})$ & $700-4500 \mu \mathrm{m}(28-180 \mathrm{~cm})$ & 8 by $1200 \mathrm{~cm}$ \\
\hline Elongate springtails & $200-5000 \mu \mathrm{m}(80-200 \mathrm{~cm})$ & $500-10000 \mu \mathrm{m}(20-400 \mathrm{~cm})$ & 15 by $40 \mathrm{~cm}$ (our component too thin) \\
\hline Oribatid mites & $30-1000 \mu \mathrm{m}(12-400 \mathrm{~cm})$ & $80-2000 \mu \mathrm{m}(32-800 \mathrm{~cm})$ & 12 by $32 \mathrm{~cm}$ \\
\hline
\end{tabular}

dall and Oades, 1982). This scale also permitted soil bacteria, having actual diameters of $0.5 \mu \mathrm{m}$, to be depicted as $2-\mathrm{mm}$ objects, which is big enough to be seen on the model. A lightweight metal frame from a discarded lab cart on four wheels ( 0.9 long by 0.5 wide by $0.8 \mathrm{~m}$ high) was used as a support for the model (Fig. 1).

\section{How Should the Model be Constructed?}

Initially, the class considered building the model in a stepwise fashion, consistent with the aggregate hierarchy theory of Tisdall and Oades (1982). This would require the students to build many small microaggregates first before gluing them together into larger microaggregates, which then would be glued together to form the final model. Although this stepwise construction approach would have been highly realistic, the class opted for ease and simplicity and chose to construct one irregular sphere as the core of the macroaggregate model.

To create a lightweight core for the model, two plastic milk crates ( 30 by 30 by $30 \mathrm{~cm}$ ) were wired together to form an internal support, and this was wired to the supporting frame (Fig. 1). The milk crates were positioned so that their openings faced outward on opposite sides. A 0.8 by $2 \mathrm{~m}$ length of chicken wire mesh was loosely wrapped around the milk crate core and pushed into the milk crate openings to depict mesopores (Table 1). Additional wire mesh was attached to the two sides and shaped to form uneven surfaces.

A papier-maché coating for the wire mesh structure was made from strips of newspaper soaked in a 10:1 water/glue solution and laid over the entire surface of the wire mesh support. The wet newspaper strips were arranged to enhance the irregular surfaces underneath. The papier-maché was air-dried for 2 days before it was spray-painted dark brown to resemble the color of humus. The model was later sprayed with splotches of another rust-colored primer paint to resemble the color of iron oxides.

\section{How Should Model Components be Depicted and Arranged?}

Each student was responsible for contributing one component to the model. Although the core of the aggregate model was an irregular sphere representing bound mineral and organic matter, students decided to portray a few individual sand grains, silt particles, and clays to demonstrate representative particle sizes in relation to the whole aggregate. In designing these abiotic components, students needed to choose an appropriate size from the range of actual sizes reported in the literature (Table 1). Biological components (discussed further below) included bacteria, fungal hyphae, protozoans, nematodes, mites, and springtails, all of which have varying size ranges as shown in Table 2. For the model organisms, the students needed to identify a suitable group or genus that would represent the organisms found in soils and decide which morphological features could be portrayed effectively. They also needed to find appropriate construction materials (e.g., rope, cardboard) and work with other students to integrate the component(s) into the model. The class was asked to consider the following: How many components of each kind should be placed on the model? Where should the component(s) be located (i.e., on the exterior of the aggregate, or inside a pore)? What types of spatial and ecological interactions can be shown between different components?

After the main aggregate structure was completed, students attached their components to the model in appropriate locations with a hot glue gun. Soybeans (representing oval bacteria) and string (representing filamentous actinomycetes) were placed inside the large cavity, or mesopore, in the front

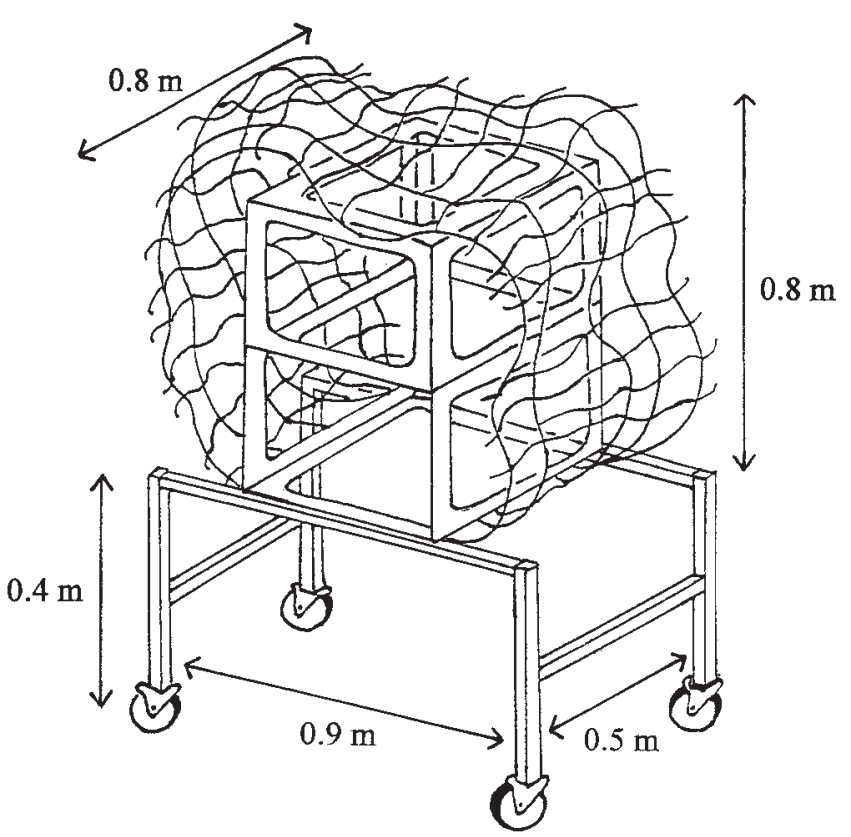

Fig. 1. Dimensions and sketch showing how the core of the model was constructed from two plastic milk crates wired together and onto a supporting frame. The core was loosely wrapped with chicken wire to create hollows and depressions prior to being coated with papier maché. 
of the soil aggregate model (Fig. 2A). Components representing larger soil organisms (ciliated protozoan, amoeba) were placed on the outside edge of the pore to demonstrate that they were too large to enter and could not graze upon the bacteria residing in the pore interior. Most students chose to make simple rather than highly detailed representations of their components.

\section{BIOLOGICAL COMPONENTS OF THE MODEL}

\section{Bacteria}

A teaspoon of topsoil can contain several billion individual prokaryotes. Prokaryotes are single-celled organisms that do not have membrane-enclosed nuclei and comprise two major groups, bacteria and archaea (Whitman et al., 1998). Since archaea represent less than $1 \%$ of total prokaryotes in soils (Buckley et al., 1998), only bacteria are discussed here. The class considered that the actual weight of their $0.25-\mathrm{mm}$ macroaggregate should be about $1 \mathrm{mg}$. This meant that their model ought to contain several million bacteria, either on or inside the model. Since strict realism was not the primary goal of the project, students distributed only about 100 bacteria in crevices and micropores, being careful to associate bacteria with organic material and organic-rich debris (Foster, 1988). It was also important to assemble microcolonies of bacteria in these locations to be consistent with electron microscopy studies showing that soil bacteria frequently occur in colonies of three to seven cells on average (Bae and Casida, 1973; Foster and Martin, 1981).

Having dealt with the question of how many bacteria should be on the model, the students next dealt with the question of bacterial size (Table 2). A review by Bakken (1997) provided students with much useful information and indicated that most soil bacteria were observed to have cell volumes smaller than 0.1 cubic $\mu \mathrm{m}$. If we assume a spherical shape for a bacterium, this volume corresponds to a cell diameter of $0.57 \mu \mathrm{m}$. Significant numbers of soil bacteria have been observed to be even smaller (diameter $<0.3 \mu \mathrm{m}$ ), and these tend to be very tightly bound to clay particles (Bakken, 1997). It was a revelation to many students that the average sizes of individual bac-

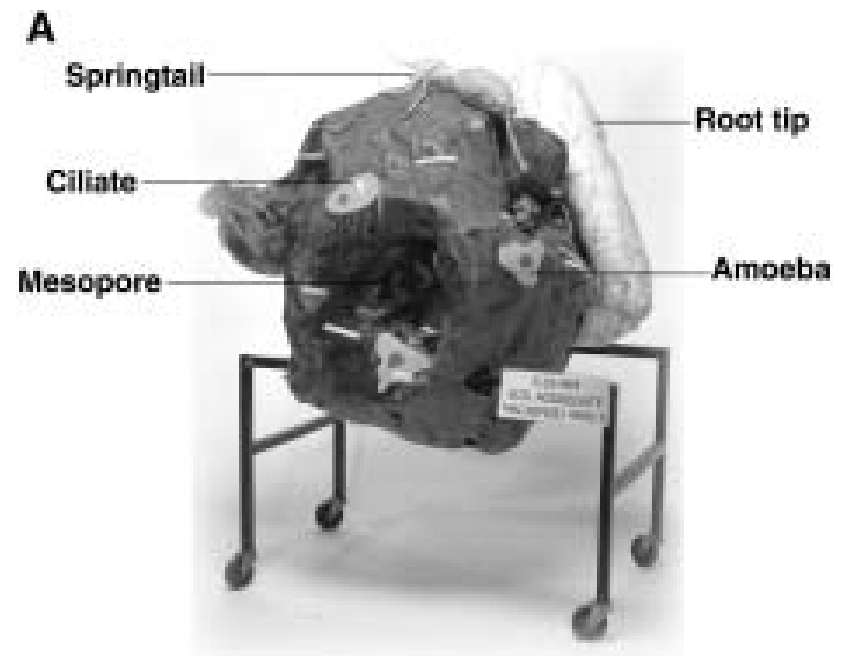

teria in nature are much smaller than those attained in laboratory cultures. This discovery helped students grasp the idea that nutrient and energy sources for organisms are scarce in most soils. Unlike laboratory culture media, which supply nonlimiting amounts of all required nutrients and uniformly favorable growth conditions, soils offer limited amounts of nutrients that are spatially heterogeneous and only sporadically available. Students decided that an average width of bacterial cells on the model should be $0.5 \mu \mathrm{m}$ to reflect nutrient limitation, or $2 \mathrm{~mm}$ wide at a scale of $4000 \times$. Rice grains served this purpose well, especially for demonstrating microcolonies of rod-shaped bacteria (Table 2). String with a width of $2 \mathrm{~mm}$ was used to portray actinomycetes, such as Streptomyces spp., which form filaments or chains of linked cells that are 0.5 to $0.8 \mu \mathrm{m}$ wide (Locci, 1989).

Another reference that impressed the students was the study by Torsvik et al. (1990), who used DNA techniques to show that a single gram of forest soil contained 4000 to 10000 different species of bacteria. This finding reinforced students' understanding that bacteria are physiologically versatile and perform a myriad of biochemical processes in soils. However, students also learned that they did not need to use a huge variety of morphological types to achieve a realistic portrayal of this enormous soil bacterial diversity. Since the small size of bacteria limits the degree to which cell morphology can vary, students needed only to show a few different shapes of bacteria on the model to be consistent with our current understanding of soil microorganisms (Bakken, 1997; Hattori, 1994; Needham et al., 2000). Beans and rice grains were used to depict oval and rod-shaped bacterial cells, respectively. Strings of varying lengths were used to depict actinomycete ("rayforming") bacteria that form filaments, or long chains of cells with varied branching patterns (Table 2).

\section{Fungi}

In their asexual stages, fungal cells divide and grow lengthwise to form hyphae (singular, hypha) that are much wider than actinomycete filaments. Saprophytic fungi obtain energy and nutrients from dead and decomposing organic matter, whereas mycorrhizal fungi obtain energy and some nu-

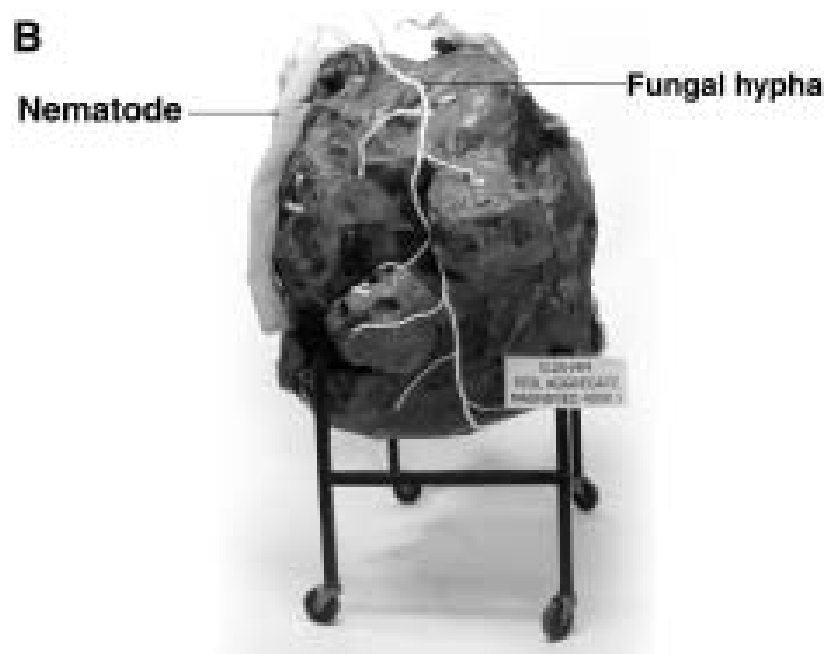

Fig. 2. Two views of the soil aggregate model. Front view A shows the "mesopore," which harbors organic matter and bacteria, with protozoans located at edge of the mesopore opening. Side view B shows the fungal hypha wrapped around the center of the aggregate and the nematode on the left side. 
trients from living plant roots. Mycorrhizae (fungus-roots) represent symbiotic associations between plant roots and fungi, which grow either on the exterior of roots and root cells (in the case of ectomycorrhizal fungi) or in the interiors of root cells (in the case of endomycorrhizae) (Bonfante-Fasolo and Scannerini, 1992). Since the model represented only an infinitesimal part of the soil, students did not concern themselves so much with the type of fungus to portray, but they did consider it important to show how fungal hyphae play important functions in soil (Miller and Jastrow, 1990). A large pipe cleaner ( $1 \mathrm{~cm}$ diameter, $1.2 \mathrm{~m}$ long) was wrapped around the aggregate to show how fungi bind together microaggregates to create and stabilize larger aggregates (Fig. 2B). Placement of the hypha on pieces of organic "debris" also demonstrated the importance of saprophytic fungi initiating organic matter decomposition (Leake et al., 2002). Because cellular contents can move through a fungal hypha toward a food source, many hyphae observed in soils are empty (devoid of cytoplasm), thus stabilizing soil structure long after biological activity has subsided (Miller and Jastrow, 1990).

\section{Protozoans}

Of all the taxonomic groups residing in soils, the protozoans (protists) have probably received the least attention from scientists. Protozoans are single-celled eukaryotic microorganisms that live in water films surrounding soil colloids, and they are morphologically and genetically diverse (Table 2). Students considered it important that their model show at least one representative of the three main groups of protozoans known to reside in soils: flagellates, ciliates, and amoebas (Cowling, 1994). Protozoans, with their different appendages used for motility, were probably the easiest and most amusing microorganisms to portray on the model. Flagellates were constructed from thin pieces of painted wood $(2$ by $6 \mathrm{~cm})$, with pipe cleaners attached to depict flagella. Ciliates were constructed by gluing together two pieces of cardboard ( 8 by 14 $\mathrm{cm}$ ) to hold numerous strings protruding from the edges to depict cilia. Amoebas, with their irregular pseudopodia, were shaped from modeling clay or cardboard $(8$ by $8 \mathrm{~cm})$. Since soil protozoans are known to be active only in the presence of fluid water, these components were located on the model in and near pores that would retain water (Fig. 2A).

\section{Nematodes}

Most students' previous knowledge of nematodes (roundworms) was limited to plant pathogens or pet parasites. Soils, however, contain a very diverse array of free-living nematodes that can be grouped on the basis of their feeding habits and mouth parts (Munn and Munn, 2002). Different types of nematodes consume bacteria, fungi, protozoans, other nematodes, other invertebrates, and live plant or animal tissue. Whereas bacterial-feeding nematodes have relatively simple mouth parts for ingesting their food by suction, predatory and plant-feeding nematodes have more complex mouths that grasp and puncture prey. In most soils, nematodes that feed on organic matter or other soil organisms greatly outnumber plant-parasitic nematodes (Freckman, 1982). Students chose to portray a bacterial-feeding nematode in their model and created one by stuffing a 1.2-m tube of brown fabric to a diameter of $8 \mathrm{~cm}$. These dimensions would represent an immature nematode at the small end of the nematode size range, which varies by almost two orders of magnitude (Table 2). The model nematode was draped on the exterior of the aggregate to show that it inhabits water films in macropore spaces (Fig. 2B). Its mouth was placed next to a microcolony of bacteria to depict its feeding habits.

\section{Mites}

Among the most abundant soil arthropods are the mites, of the order Acari, which exhibit a wide range of morphologies and sizes (Kevan, 1965; Walter and Proctor, 1999). Temperate forest soils, for example, contain 57000 to 680000 mites/m² (Coleman and Crossley, 1996, p. 75), whereas notillage agricultural soils contain $78000 / \mathrm{m}^{2}$ (Hendrix et al., 1986). The three main taxonomic groups of mites found in soils are oribatids, prostigmatids, and mesostigmatids. Oribatid mites are mostly fungivores and detritivores, although some prey on nematodes. Prostigmatids mostly feed on plant fluids, whereas mesostigmatids are generally arthropod predators (Moore et al., 1988). For the model, one mesostigmatid mite was made from construction paper and placed on the outside of the aggregate model to demonstrate that it was restricted to inhabiting spaces between soil aggregates.

\section{Collembola}

Collembola are six-legged arthropods related to the insects, although they are considered more primitive than insects (Hopkin, 1997). Collembola are very abundant in many soils, ranging from 7500 to $71000 / \mathrm{m}^{2}$ in temperature forest soils (Coleman and Crossley, 1996, p. 75) and up to $14000 / \mathrm{m}^{2}$ in no-tillage agricultural soils (Hendrix et al., 1986). The common name for collembola, "springtails," refers to the jumping organs (furcula) located at the ends of the abdomens of many species. Collembola vary in size by as much as two orders of magnitude (Table 2), and they are classified on the basis of morphology, reflecting their adaptations to different depths in soil or litter (Hopkin, 1997). Collembola that reside in litter layers or at the soil surface have well-developed furcula, which enable them to jump long distances to escape predators. Surface-dwelling collembola also tend to be larger and more darkly pigmented than collembola that dwell at greater depths in the soil, and many of the latter have furcula that no longer function in jumping. Two main collembolan groups are recognized on the basis of body shape. Symphypleona, or the globular collembola, have rounded bodies and include the sminthurids and neelids. Arthropleona collembolan have elongated body shapes and include the poduromorpha and entomobryomorpha collembolans (Hopkins, 1997). The former tend to live out their lives in deeper soil and humus, whereas the latter may live in litter, surface soil, or both. Students constructed an elongate collembolan $(15$ by $40 \mathrm{~cm})$ with a developed furcula to reflect that it dwells in a surface soil.

\section{Fine Roots}

As indicated in Table 2, the model's exterior (macropore space) was the site for placing the model's fine root tip, made from a stuffed nylon stocking $(25 \mathrm{~cm}$ wide) with attached pieces of yarn depicting root hairs. The root tip was positioned superficially on the model so that it looked like the root was 
growing between the model and neighboring macroaggregates. By including a fine root tip in the model, students could point out to their audiences that food sources for the soil community are derived from living organisms as well as dead organic material.

\section{Other Organisms}

Many other opportunities existed for students to add representations of rarer (or less studied) soil organisms to the model. These included primitive microarthropods like the proturans, symphylans, and diplurans, and other mesofauna such as enchytraeid worms (Wallwork, 1970). The diversity and complexity of components considered for this type of project therefore depends on the scale of magnification chosen, the students' curiosity about little-known taxa, and their willingness to put time and effort into researching and creating realistic representations based on images in the literature (Eisenbeis and Wichard, 1987). Students can consult references cited in this article to obtain additional information about the diversity, density, and distribution of less common groups of soil fauna (Dindal, 1990; Kevan, 1965).

\section{Food Web Interactions}

The final steps in assembling the aggregate model provided numerous opportunities for students to discuss and integrate their understanding of soil ecological concepts. In addition to portraying how soil organisms influence their own microhabitats, students used the model to show how soil organisms interact with each other in a highly complex food web. Of fundamental importance was the model's portrayal of how organic matter is the basis for all food web interactions. By incorporating a root tip component into the model, students illustrated that the soil community obtains food not only from dead or decomposing organic matter, but from living plants as well. Students were thus able to demonstrate the rhizosphere effect, or the increased density of soil bacteria, fungi, and protozoans in the zone immediately adjacent $(<2 \mathrm{~mm}$ ) to active roots (Foster and Martin, 1981). Up to 100-fold higher density of soil organisms can be observed in the rhizosphere because of the increased concentrations of nutrients that are secreted, leaked, or sloughed off by active roots (Oades, 1993). The connection between soil organisms and their food supply was further reinforced in the model by consistently associating the microcolonies of soil bacteria with patches of organic matter (Table 1).

Predator-prey relationships in the soil food web were very easy to depict with the model. Soil bacteria were shown to serve as prey for such larger soil organisms as protozoans and nematodes. Since some soil bacteria (e.g., Bdellovibrio spp. and Cupriavidus necator) have been observed to consume other bacteria, these interactions could also be portrayed (Casida, 1988). The most dramatic predator-prey relationship depicted on the current model was between a fungus (e.g., Arthrobotrys sp.) and a nematode (Barron, 1992). The nematode was shown to be immobilized and trapped by an adhesive loop formed by the nematode-trapping fungus, which would be capable of secreting enzymes to penetrate and digest its prey (Dackman et al., 1992). Through the model's visual representations of biological interactions, the practical benefits of soil biotic diversity could be demonstrated by showing how indigenous soil organisms feed on pathogenic or otherwise destructive pests. Class discussions of food web complexity led students to recognize how increased activity of indigenous soil organisms can serve to keep pest populations low.

\section{Instructional Materials}

Students wrote short paragraphs describing their components to be used in educational materials accompanying the model. Students were encouraged to write in nontechnical language that would appeal to middle school students, who were the target audience for AgroEcology Day. In some cases, labels were added to the model to help the audience understand what a particular component represented. The fundamental message of the soil aggregate model was this: Living and dead organic matter constitute the foundation of the soil food web; organic matter additions and continuous vegetative cover can be used to build up and diversify soil biotic communities, thereby providing indirect benefits of greater nutrient availability to plants and biological control of pests (Elliott and Coleman, 1988).

\section{AUDIENCE REACTIONS AND QUESTIONS}

After the course was over, the students' aggregate model became a popular visual aid for describing the soil ecological community in other soil science courses, agricultural field days, and outreach programs in elementary and secondary schools. Because the model was transportable and relatively durable, students and faculty exhibited the model at events like the Pennsylvania Farm Show, Ag Progress Days, and the Great Insect Fair organized by the Penn State Department of Entomology. Since its construction in fall 2000, approximately 1200 people have viewed the aggregate model, received brief explanations, and been given the opportunity to ask questions. One of the most frequently asked questions is, "Where's the earthworm?" The answer to this question is that a typical earthworm at 4000× magnification would be $16 \mathrm{~m}$ wide and $600 \mathrm{~m}$ long (Edwards and Bohlen, 1996)! This answer never fails to amuse the audience and seems to help viewers assimilate new information about soil organisms.

Audiences have also frequently asked about the effect of pesticides on soil organisms. The best response to this question is that we know very little about the long-term effects of pesticides on diverse, nontarget organisms (Rusek, 2000). This question is much more difficult to answer than the related question, "What would happen if all soil organisms became extinct?" Students have responded by pointing out that we would soon be buried in our own wastes in a world devoid of soil microorganisms (Needham et al., 2000). One of the most surprising comments came from a high school teacher who expressed concern about all the germs in soil and about the need to protect ourselves from them. In asking how we might disinfect soils, this teacher was overlooking all of the beneficial, and indeed necessary, functions performed by microorganisms in our lives (Needham et al., 2000). As E.O. Wilson (2002) points out, the future of life depends on increasing our knowledge and understanding of the biological worlds unseen by us. More than ever, educators need to facilitate people's access to unseen worlds. The scale model of a soil aggregate and its resident biological community provides a highly effective 
and engaging method to educate audiences of all generations about the incredible diversity of life underground.

\section{ACKNOWLEDGMENTS}

The authors gratefully acknowledge support from the Joan Luerrsen Faculty Enhancement Fund in the PSU College of Agricultural Sciences. We also thank all the students in the PSU Soil Ecology class of 2000 who helped construct the aggregate model: Amy Baranowski, Mike Callahan, Jaime Carson, Brad Georgic, Duane Goodsell, Andy Heggenstaller, Zak Keegan, Wuxing Li, Chris McKeon, Brian McMullen, Eric Nachtman, Brandon Novogradac, Sarah Rider, Marie Riegner, Liz Tuck, Jason Watson, and Galim Zhunisbekov.

\section{REFERENCES}

Bae, H.C., and L.E. Casida. 1973. Responses of indigenous soil microorganisms to soil incubations as viewed by transmission electron microscopy of cell thin sections. J. Bacteriol. 113:1462-1473.

Bakken, L.R. 1997. Culturable and nonculturable bacteria in soil. p. 47-61. In J.D. van Elsas et al. (ed.) Modern soil microbiology. Marcel Dekker, New York.

Barron, G.L. 1992. Lignolytic and cellulolytic fungi as predators and parasites. p. 311-326. In G. Carroll and D.T. Wicklow (ed.) The fungal community: Its organization and role in the ecosystem. 2nd ed. Marcel Dekker, New York.

Bonfante-Fasolo, P., and S. Scannerini. 1992. The cellular basis of plant-fungus interchanges in mycorrhizal associations. p. 65-101. In M.F. Allen (ed.) Mycorrhizal functioning: An integrative plant-fungal process. Chapman and Hall, New York.

Buckley, D.H., J.R. Graber, and T.M. Schmidt. 1998. Phylogenetic analysis of nonthermophilic members of the kingdom Crenarchaeota and their diversity and abundance in soils. Appl. Environ. Microbiol. 64:4333-4339.

Casida, L.E. 1988. Minireview: Nonobligate bacterial predation of bacteria in soils. Microb. Ecol. 15:1-8.

Coleman, D.C., and D.A.K. Crossley. 1996. Fundamentals of soil ecology. Academic Press, San Diego, CA.

Cowling, A.J. 1994. Protozoan distribution and adaptation. p. 5-42. In J.F. Darbyshire (ed.) Soil protozoa. CABI Publ., Wallingford, UK.

Dackman, C., H.-B. Jansson, and B. Nordbring-Hertz. 1992. Nematophagous fungi and their activities in soil. p. 95-130. In G. Stotzky and J.-M. Bollag (ed.) Soil biochemistry. Vol. 7. Marcel Dekker, New York.

Dindal, D.L. 1990. Soil biology guide. John Wiley \& Sons, New York.

Edwards, C.A., and P.J. Bohlen. 1996. Biology and ecology of earthworms. Chapman and Hall, London.

Eisenbeis, G., and W. Wichard. 1987. Atlas on the biology of soil arthropods. Springer-Verlag, New York.

Elliott, E.T., and D.C. Coleman. 1988. Let the soil work for us. Ecol. Bull. 39:23-32.

Foster, R.C. 1988. Microenvironments of soil microorganisms. Biol. Fertil. Soils 6:189-203.

Foster, R.C., and J.K. Martin. 1981. In situ analysis of soil components of biological origin. p. 75-110. In E.A. Paul and J.N. Ladd (ed.) Soil biochemistry. Vol. 5. Marcel Dekker, New York.
Freckman, D.W. 1982. Parameters of the nematode contribution to ecosystems. p. 81-97. In D.W. Freckman (ed.) Nematodes in soil ecosystems. Univ. of Texas Press, Austin, TX.

Gale, J., C.A. Cambardella, and T.B. Bailey. 2000. Root-derived carbon and the formation and stabilization of aggregates. Soil Sci. Soc. Am. J. 64:201-207.

Hattori, T. 1994. The soil microenvironment. p. 43-64. In J.F. Darbyshire (ed.) Soil protozoa. CABI Publ., Wallingford, UK.

Hendrix, P.F., R.W. Parmelee, D.A. Crossley, Jr., D.C. Coleman, E.P. Odum, and P.M. Groffman. 1986. Detritus food webs in conventional and notillage agroecosystems. BioScience 36:374-380.

Hopkin, S.P. 1997. Biology of the springtail (Insecta: Collembola). Oxford Univ. Press, New York.

Kevan, D.K.McE. 1965. The soil fauna: Its nature and biology. p. 33-50. In R.R. Baker and W. C. Snyder (ed.) Ecology of soil-borne plant pathogens. Univ. of California Press, Berkeley CA.

Leake, J.R., D.P. Donnelly, and L. Boddy. 2002. Interactions between ectomycorrhizal fungi and saprotrophic fungi. p. 345-372. In M.G.A. van der Heijden and I.R. Sanders (ed.) Mycorrhizal ecology. Springer-Verlag, New York.

Locci, R. 1989. Streptomycetes and related genera. p. 2451-2508. In S.T. Williams (ed.) Bergey's manual of systematic bacteriology. Vol. 4. Williams \& Wilkins, Philadelphia.

Miller, R.M., and J.D. Jastrow. 1990. Hierarchy of root and mycorrhizal fungal interactions with soil aggregation. Soil Biol. Biochem. 22:579-584

Moore, J.C., D.E. Walter, and H.W. Hunt. 1988. Arthropod regulation of micro- and mesobiota in below-ground detrital food webs. Ann. Rev. Entomol. 33:419-439.

Munn, E.A., and P.D. Munn. 2002. Feeding and digestion. p. 211-232. In D.L. Lee (ed.) The biology of nematodes. Taylor and Francis, New York.

Needham, C., M. Hoagland, K. McPherson, and B. Dodson. 2000. Intimate strangers: Unseen life on earth. ASM Press, Washington, DC.

Oades, J.M. 1993. The role of biology in the formation, stabilization, and degradation of soil structure. Geoderma 56:377-400.

Rusek, J. 2000. Soil invertebrate species diversity in natural and disturbed environments. p. 233-252. In D.C. Coleman and P.F. Hendrix (ed.) Invertebrates as webmasters in ecosystems. CABI Publ., New York.

Six, J., E.T. Elliott, and K. Paustian. 1999. Aggregate and soil organic matter dynamics under conventional and no-tillage systems. Soil Sci. Soc. Am. J. 63:1350-1358.

Six, J., E.T. Elliott, K. Paustian, and J.W. Doran. 1998. Aggregation and soil organic matter accumulation in cultivated and native grassland soils. Soil Sci. Soc. Am. J. 62:1367-1377.

Thomas, G.W., and R.E. Phillips. 1979. Consequences of water movement in macropores. J. Environ. Qual. 8:149-152.

Tisdall, J.M. 1994. Possible role of soil microorganisms in aggregation in soils. Plant Soil 159:115-121.

Tisdall, J.M., and J.M. Oades. 1982. Organic matter and water-stable aggregates in soils. J. Soil Sci. 33:141-163.

Torsvik, V., F.L. Daae, and J. Goksoyr. 1990. High diversity in DNA of soil bacteria. Appl. Environ. Microbiol. 56:782-787.

Wallwork, J.A. 1970. Ecology of soil animals. McGraw-Hill, London.

Walter, D.E., and H.C. Proctor. 1999. Mites: Ecology, evolution, and behavior. CABI Publ., New York.

Whitman, W.B., D.C. Coleman, and W.J. Wiebe. 1998. Prokaryotes: The unseen majority. Proc. Natl. Acad. Sci. USA 95:6578-6583.

Wilson, E.O. 2002. The future of life. Alfred A. Knopf, New York. 